Dokuz Eylül Üniversitesi-Mühendislik Fakültesi

Fen ve Mühendislik Dergisi

Cilt 19, Sayı 56, Mayıs 2017
Dokuz Eylul University-Faculty of Engineering Journal of Science and Engineering Volume 19, Issue 56, May 2017

DOI: $10.21205 /$ deufmd.2017195649

\title{
Thermal Comfort Properties of Fabrics Knitted from Bamboo/Cotton Blended Yarns
}

\author{
Hüseyin Gazi TÜRKSOY*, Sümeyye ÜSTÜNTAĞ, Gurbet ÇARKIT
}

Erciyes Üniversitesi, Mühendislik Fakültesi, Tekstil Mühendisliği Bölümü, 38039, KAYSERI

(Alınış / Received: 23.11.2016, Kabul / Accepted: 06.02.2017, Online Yayınlanma / Published Online: 02.05.2017)

Keywords

Bamboo fiber, Thermal comfort properties, Air permeability, Water vapor resistance, Thermal resistance.

\begin{abstract}
In this research, some thermal comfort properties of fabrics knitted from 70/30 \% bamboo/cotton blended yarns were investigated in comparison with fabrics which have different structures (plain knit, pique knit and double knit,) and raw materials (cotton, modal and cotton/modal). The results reveal that measured thermal comfort properties of bamboo/cotton knitted fabrics change depending on fabric structure and fabric type. The air permeability values of bamboo/cotton blended knits were higher for pique fabric as compared to those values of double and plain knit fabrics. Also, it was observed that 70/30\% bamboo/cotton double knit fabrics have the lowest water vapor resistance and thermal resistance values as compared to other double knit fabrics which have different raw materials.
\end{abstract}

\section{Bambu/Pamuk Karışımlı İpliklerden Örülen Kumaşların Termal Konfor Özellikleri}

\begin{abstract}
Anahtar Kelimeler Özet: Bu çalışmada, \%70/30 bambu/pamuk karışımlı ipliklerden Bambu lifi, Termal konfor özellikleri, Hava geçirgenliği, Su buharı direnci, Termal direnç. örülen kumaşların termal konfor özellikleri farklı yapı (süprem, lacoste ve ribana) ve hammaddelere (pamuk, modal, pamuk/modal) sahip kumaşlar ile karşılaștırılmalı olarak incelenmiştir. Çalışma sonucunda, bambu/pamuk karışımlı ipliklerden örülen kumașların termal konfor özelliklerinin kumaș yapısı ve lif tipine bağlı olarak değiştiği görülmüştür. Lacoste bambu/pamuk karışımlı kumaşların hava geçirgenliği değerleri süprem ve ribana kumaşlara göre daha yüksek çıkmıștır. Ayrıca, $\% 70 / 30$ bambu/pamuk ribana kumaşların, diğer hammaddeler ile örülen ribana kumaşlara göre daha düşük su buharı ve termal dirence sahip olduğu görülmüştür.
\end{abstract}




\section{H. G. TÜRKSOY, S. ÜSTÜNTAĞ, G. ÇARKIT / Thermal Comfort Properties of Fabrics Knitted from}

Bamboo/Cotton Blended Yarns

\section{Introduction}

Garment comfort, which can be defined as a pleasant state of psychological and physical harmony between a human being and environment, became the most important purchasing criterion sought by consumers. Comfort is influenced by fabric factors, fiber properties, environment and human factors etc [1]. Clothing comfort includes three main considerations: psychological, sensorial and thermo-physiological comfort. As a result of increasing demand for clothing comfort, there are many studies related to the comfort properties of fabrics. In several previous studies, the influence of fibers and textile structures on the comfort of fabrics has been investigated [2-6].

Das at al. [7] have underlined that the processes which play the major role in moisture transmission in a particular situation are dependant on the moisture content of the fabric, the type of material used, the perspiration rate and the atmospheric conditions, such as humidity, temperature and wind speed. Oğlakçioğlu and Marmarali [8] have observed that each knitted structure tends to yield rather different thermal comfort properties. Nayak at al. [9] investigated that the effects of polyester content, pick density and weave on the thermal comfort and tactile properties of polyester/viscose blended yarn fabrics. They found that the fabrics with higher polyester content give higher total hand value and higher thermal insulation, but lower air permeability and lower moisture vapour transfer. Onefrei at al. [10] found that some properties, such as, thermal properties, diffusion ability, air and water vapor permeability are influenced by both raw material type and knitted parameters. Troynikov at al. [11] have determined that blending wool with polyester or wool with bamboo has improved moisture management properties of the fabrics in comparison to
$100 \%$ wool and $100 \%$ bamboo fabrics. Namligöz at al. [12] focused on the evaluation of indices of liquid moisture management properties, grading and classification methods of woven fabrics with various fibers by using MMT tester. They found that unlike 100\% Cellulosic and PES fabrics, Cellulosic/PES blended fabrics allowed the liquid absorption and transportation efficiently. Prakash at al. $[13,14]$ found that the thermal conductivity, thermal resistance, air permeability and relative water-vapour permeability values of the fabrics depend on bamboo fibre content in the fabric and the linear density of the constituent yarns. Atasağun at al. [15] have examined the advantages of Viloft blends (Coolmax, Thermolite, wool, polyester, and acrylic) used for sportswear. The analyses have indicated that Viloft/Wool fabrics showing high thermal resistance and high water vapor resistance have poor performance with respect to transfer properties.

Bamboo is one of the fastest growing plants and available abundantly in many countries. Because of being naturally abundant, cheap and also ecological, bamboo fiber has gained in popularity in the production of a wide range of textile fabrics in recent years $[6,16]$. In addition, thanks to natural antibacterial and biodegradable properties, high moisture absorption capacity, softness, and brightness as well as UV protective characteristics of bamboo fibers, bamboo textile products have started to edge into the textile market.

Currently, there are two ways to utilize bamboo in the textile industry. One is to produce natural fiber from bamboo by chemical and physical treatment (this material is called natural bamboo fiber). However, this process is seldom used, because it is labor intensive and costly. The other method is to spin the regenerated fiber after the bamboo is 


\section{H. G. TÜRKSOY, S. ÜSTÜNTAĞ, G. ÇARKIT / Thermal Comfort Properties of Fabrics Knitted from}

Bamboo/Cotton Blended Yarns

retted into bamboo pulp (this material is called regenerated bamboo fiber) [17]. Regenerated bamboo fibers are produced in a wet spun process in which natural cellulose (in this case originating from crushed bamboo leaves and stems) is used as raw material in a hydrolysisalkalization process $[18,19]$.

In the literature, natural bamboo fibers are commonly compared with ramie fibers whereas regenerated bamboo fibers with cotton and viscose fibers [2022]. Bamboo is very common to blend existing fiber types to acquire fabrics with enhanced performance and improved aesthetic qualities as well as low cost. In this study, some thermal comfort properties of fabrics knitted from 70/30 \% bamboo/cotton blended yarns were investigated comparatively with fabrics which have different fabric structures and raw materials.

\section{Material and Method}

In this study, yarn samples were manufactured from 70/30 \% bamboo/cotton, $100 \%$ cotton, $100 \%$ modal, 50/50 \% modal-cotton at the count of $\mathrm{Ne} 30 / 1$ with ring spinning system. Firstly, plain, pique and doubleknit fabric samples were manufactured from $70 / 30 \%$ bamboo/cotton blended yarns. The knit notations can be seen in Figure 1. Then, double knit fabrics were also manufactured from $100 \%$ cotton, $100 \%$ modal, $50 / 50 \%$ modal/cotton yarn samples.

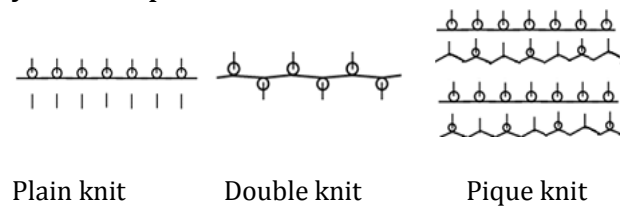

Figure 1: Knit notations of fabric samples.
The plain knit and pique knit fabrics were knitted on a Mayer MV 4-3-2II model circular knitting machine having gauge of E28, 19 inch diameter with 60 feeders while double-knit fabrics were knitted on a Mayer F.V.2.0 model circular knitting machine having gauge of E18, 14 inch diameter with 29 feeders. Each fabric sample was produced at the same stitch length which was determined as $0.33 \mathrm{~cm}$. Table 1 shows codes and structural parameters of fabric samples.

To evaluate of thermal comfort properties of the fabric samples, fabric thickness, air permeability, water vapor resistance and thermal resistance tests were performed. Thickness values of the fabrics were determined according to ASTM D 1777-96 by James Heal R\&B Cloth Thickness Tester [14]. Air permeability of the knitted fabrics, defined as the volume of air measured in cubic meters passed per minute through a square meter of fabric at a constant pressure, was measured by a standard testing device. Five tests were carried out on FX-Textest 3300 air permeability test instrument for each fabric type at the same air pressure (100 pascal) according to ISO 9237 standard [15].

Water vapor resistance is the demonstrated resistance of material against water vapor passage [16]. Water vapor resistance was determined by Permetest instrument according to ISO 11092 standard [17]. Working principle of Permetest instrument consists of measuring the dynamic heat flow caused by the evaporation of water passing through the tested specimen. 
H. G. TÜRKSOY, S. ÜSTÜNTAĞ, G. ÇARKIT / Thermal Comfort Properties of Fabrics Knitted from

Bamboo/Cotton Blended Yarns

Table 1. Codes and structural parameters of fabric samples.

\begin{tabular}{|c|c|c|c|c|}
\hline Code & Content & $\begin{array}{c}\text { Fabric } \\
\text { Structure }\end{array}$ & $\begin{array}{c}\text { Mass per } \\
\text { unit area } \\
\mathrm{g} / \mathrm{m}^{2}\end{array}$ & $\begin{array}{l}\text { Stitch Density } \\
\text { stitch/cm }^{2} \\
\text { (cpc*wpc) }\end{array}$ \\
\hline A & $\begin{array}{c}70 / 30 \% \\
\text { Bamboo/ Cotton }\end{array}$ & Plain & 116.32 & $\begin{array}{c}182 \\
(14 * 13)\end{array}$ \\
\hline B & $\begin{array}{c}70 / 30 \% \\
\text { Bamboo/ Cotton }\end{array}$ & Pique & 125.68 & $\begin{array}{c}90 \\
(9 * 10)\end{array}$ \\
\hline $\mathrm{C}$ & $\begin{array}{c}70 / 30 \% \\
\text { Bamboo/ Cotton }\end{array}$ & Double & 157.05 & $\begin{array}{c}110 \\
\left(11^{*} 10\right)\end{array}$ \\
\hline $\mathrm{D}$ & $100 \%$ Cotton & Double & 176.18 & $\begin{array}{c}130 \\
(13 * 10) \\
\end{array}$ \\
\hline $\mathrm{E}$ & $100 \%$ Modal & Double & 178.76 & $\begin{array}{c}130 \\
\left(13^{*} 10\right)\end{array}$ \\
\hline $\mathrm{F}$ & $\begin{array}{c}50 / 50 \% \\
\text { Modal/Cotton }\end{array}$ & Double & 173.13 & $\begin{array}{c}143 \\
\left(13^{*} 11\right)\end{array}$ \\
\hline
\end{tabular}

Thermal resistance is a measure of the body's ability to prevent heat from flowing through it $[16,18]$. Thermal resistance represents the temperature difference between the two sides of the material, distributed by unit area to the heat flow in gradient direction. The thermal resistance, expressed into Kelvin square meters/Watt is a quantity specific to textile materials or composites, which determines the dry heat flow by a given surface when a time stable temperature gradient is applied. Thermal resistance of the fabrics was measured using sweating guarded hot plate test method according to ISO 11092 standard [17].

The $300 \times 300 \mathrm{~mm}^{2}$ specimen to be tested was placed on the heated test plate. In order to determine the thermal resistance, the heat flux through the specimen was measured after steadystate conditions have been reached. During the tests, the sweating guarded hotplate was placed into an air conditioned chamber. The ambient temperature was set at $20^{\circ} \mathrm{C}$ and test plate was maintained at $35^{\circ} \mathrm{C}$. The air speed was maintained at $1 \mathrm{~m} / \mathrm{s}$ and the relative humidity was maintained at 65 $\%$. The specific thermal resistance of textile materials was determined as the quotient of the temperature difference between the measuring plate and the air and the specific heat flux through the fabric sample.

SPSS 13.0 for Windows statistical software was used for evaluating test outcomes. To determine the statistical importance of the variations, one way analysis of variance (ANOVA) tests were applied. To deduce whether the parameters were significant or not, $p$ values were examined. If the $p$ value of a parameter is greater than $0.05(p>0.05)$, being not important, the parameter can be omitted. The mean difference of subgroups was compared and interpreted for only statistically significant factors by using Tukey test (Multiple Comparisons) at $95 \%$ significance level. If the mean difference (I-J) is positive, the value of factor (I) is higher than that of factor (J). In contrast, if the mean difference (I-J) is negative that means the value of factor $(\mathrm{J})$ is higher compared to the value of factor (I).

\section{Results}

The test results were evaluated for two different categories as different fabric structures and different raw materials. The average thickness values of fabric samples are shown graphically in Figure 2. Fabric thickness was firstly evaluated for different fabric structures. As seen in 


\section{H. G. TÜRKSOY, S. ÜSTÜNTAĞ, G. ÇARKIT / Thermal Comfort Properties of Fabrics Knitted from}

Bamboo/Cotton Blended Yarns

Figure 2, the thickness value of double knit (C) fabric is higher than that of pique (B) and plain knit (A) fabric. Based on the ANOVA results, the fabric structure has a significant influence on the thickness values $(\mathrm{p}=0.000)$. According to the Tukey results, the thickness value of double knit fabrics is significantly higher than that of other fabrics as seen in Table 2.

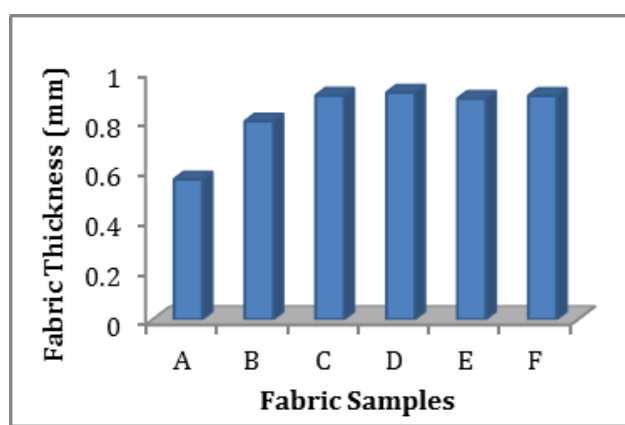

Figure 2. Thickness values of fabric samples.

Fabric thickness was also evaluated for different raw materials. As seen in Figure 2 , the thickness value of $70 / 30 \%$ Bamboo/Cotton (C) fabric is lower than that of $100 \%$ Cotton (D) fabric and higher than that of $100 \%$ Modal (E) and $50 / 50 \%$ Modal/ Cotton (F) fabrics. On the other hand, based on ANOVA test results, the differences between thickness values of the fabrics produced from different raw materials were found to be statistically insignificant $(\mathrm{p}=0.358)$.

Table 2. Multiple comparisons of knitted structures for thickness value.

\begin{tabular}{|c|c|c|c|}
\hline $\begin{array}{c}\text { Fabric } \\
\text { Type } \\
\text { (I) }\end{array}$ & $\begin{array}{c}\text { Fabric } \\
\text { Type } \\
\text { (J) }\end{array}$ & $\begin{array}{c}\text { Mean } \\
\text { Difference } \\
\text { (I-J) }\end{array}$ & $\begin{array}{c}\text { Significance } \\
\text { (P) }\end{array}$ \\
\hline \multirow{2}{*}{$\mathrm{A}$} & $\mathrm{B}$ & -0.2340 & 0.000 \\
\cline { 2 - 4 } & $\mathrm{C}$ & -0.3380 & 0.000 \\
\hline \multirow{2}{*}{$\mathrm{B}$} & $\mathrm{A}$ & 0.2340 & 0.000 \\
\cline { 2 - 4 } & $\mathrm{C}$ & -0.1040 & 0.000 \\
\hline $\mathrm{C}$ & $\mathrm{A}$ & 0.3380 & 0.000 \\
\cline { 2 - 4 } & $\mathrm{B}$ & 0.1040 & 0.000 \\
\hline
\end{tabular}

Air permeability was firstly evaluated for different fabric structures. Based on the ANOVA results, the fabric structure has a significant influence on the air permeability values of bamboo/cotton fabrics $(p=0.000)$. In Figure 3, air permeability values of the fabric samples are given graphically. From the results presented in Figure 3, it can be stated that the highest air permeability value was obtained from pique knit (B) fabric. As seen in Table 1, fabric $B$ has the lowest stitch density which means higher macro porosity. In addition, Tukey test results show that the difference between air permeability values of pique knit (B) and other fabric structures (A, C) are statistically significant whereas the difference between air permeability values of double knit (C) and plain knit (A) fabrics is insignificant (Table 3 ).

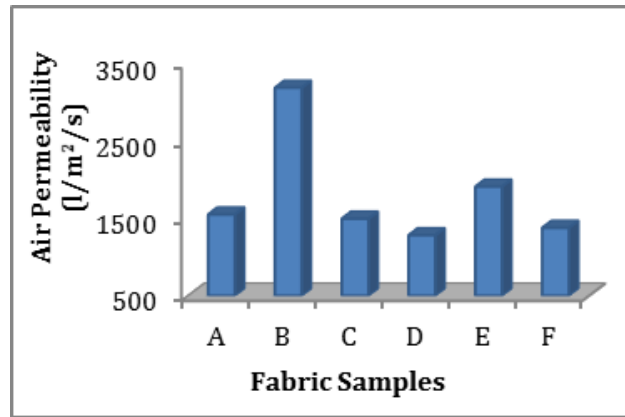

Figure 3. Air permeability values of fabric samples.

Air permeability was also evaluated for different raw materials. According to ANOVA test results, it is found that the raw material has a statistically significant influence on the air permeability values $(p=0.000)$.

Table 3. Multiple comparisons of knitted structures for air permeability.

\begin{tabular}{|c|c|c|c|}
\hline $\begin{array}{c}\text { Fabric } \\
\text { Type } \\
\text { (I) }\end{array}$ & $\begin{array}{c}\text { Fabric } \\
\text { Type } \\
\text { (J) }\end{array}$ & $\begin{array}{c}\text { Mean } \\
\text { Difference } \\
\text { (I-J) }\end{array}$ & $\begin{array}{c}\text { Significance } \\
\text { (P) }\end{array}$ \\
\hline \multirow{2}{*}{$\mathrm{A}$} & $\mathrm{B}$ & -1636.00 & 0.000 \\
\cline { 2 - 4 } & $\mathrm{C}$ & 54.00 & 0.342 \\
\hline \multirow{2}{*}{$\mathrm{B}$} & $\mathrm{A}$ & 1636.00 & 0.000 \\
\cline { 2 - 4 } & $\mathrm{C}$ & 1690.00 & 0.000 \\
\hline \multirow{2}{*}{$\mathrm{C}$} & $\mathrm{A}$ & -54.00 & 0.342 \\
\cline { 2 - 4 } & $\mathrm{B}$ & -1690.00 & 0.000 \\
\hline
\end{tabular}

As seen in Figure 3, the air permeability value of $70 / 30 \%$ bamboo/cotton (C) fabric is higher than that of $100 \%$ cotton 


\section{H. G. TÜRKSOY, S. ÜSTÜNTAĞ, G. ÇARKIT / Thermal Comfort Properties of Fabrics Knitted from}

Bamboo/Cotton Blended Yarns

(D) and 50/50 \% modal/cotton fabric

(F). However, the differences between air permeability values of $70 / 30 \%$ bamboo/cotton (C) with \%100 cotton (D) and 50/50 \% modal/cotton (F) fabrics were found to be insignificant. Furthermore, the differences between air permeability values of 70/30 \% bamboo/cotton (C) with \%100 modal (E) fabrics were found to be significant (Table 4).

Table 4. Multiple comparisons of raw materials for air permeability.

\begin{tabular}{|c|c|c|c|}
\hline $\begin{array}{c}\text { Fabric } \\
\text { Type } \\
\text { (I) }\end{array}$ & $\begin{array}{c}\text { Fabric } \\
\text { Type } \\
\text { (J) }\end{array}$ & $\begin{array}{c}\text { Mean } \\
\text { Difference } \\
\text { (I-J) }\end{array}$ & $\begin{array}{c}\text { Significance } \\
\text { (P) }\end{array}$ \\
\hline \multirow{2}{*}{ C } & D & 214.00 & 0.302 \\
\cline { 2 - 4 } & E & -414.00 & 0.014 \\
\cline { 2 - 4 } & $\mathrm{F}$ & 118.00 & 0.751 \\
\hline \multirow{2}{*}{ D } & $\mathrm{C}$ & -214.00 & 0.302 \\
\cline { 2 - 4 } & $\mathrm{E}$ & -628.00 & 0.000 \\
\cline { 2 - 4 } & $\mathrm{F}$ & -96.00 & 0.847 \\
\hline \multirow{3}{*}{$\mathrm{E}$} & $\mathrm{C}$ & 414.00 & 0.014 \\
\cline { 2 - 4 } & $\mathrm{D}$ & 628.00 & 0.000 \\
\cline { 2 - 4 } & $\mathrm{F}$ & 532.00 & 0.002 \\
\hline \multirow{3}{*}{$\mathrm{F}$} & $\mathrm{C}$ & -118.00 & 0.751 \\
\cline { 2 - 4 } & $\mathrm{D}$ & 96.00 & 0.847 \\
\cline { 2 - 4 } & $\mathrm{E}$ & -532.00 & 0.002 \\
\hline
\end{tabular}

Water vapor resistance was firstly evaluated for different fabric structures. According to the ANOVA test results, the fabric structure has a significant influence on the water vapor resistance $(p=0.028)$. The average water vapor resistance values of the fabric samples are shown graphically Figure 4.

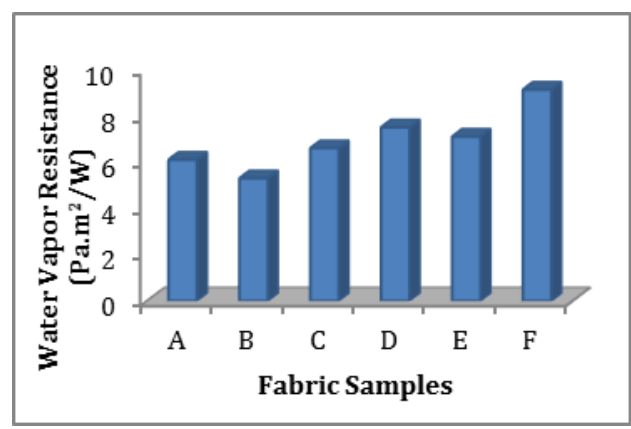

Figure 4. Water vapor resistance values of fabric samples.
As seen in Figure 4, the water vapor resistance value of double knit (C) fabric is higher than that of pique (B) and plain knit (A) fabric. In addition, according to Tukey test results, the difference between water vapor resistance values of double knit (C) and pique (B) fabrics was found to be statistically significant while the difference between the double knit (C) and plain knit (A) was found to be insignificant (Table 5). This situation could be related with the comparatively higher stitch density and thickness values of the double knit fabrics (C) in comparison to pique knit (B) fabrics. Even though double knit fabrics (C) have lower stitch density than plain knit fabrics (A), the placement of the loops in the double knit fabrics compensates this by accommodating more fibers through the thickness direction as the thickness of the double knit fabrics is significantly higher than plain knit fabrics (Table 2).

Table 5. Multiple comparisons of knitted structures for water vapor resistance.

\begin{tabular}{|c|c|c|c|}
\hline $\begin{array}{c}\text { Fabric } \\
\text { Type } \\
\text { (I) }\end{array}$ & $\begin{array}{c}\text { Fabric } \\
\text { Type } \\
\text { (J) }\end{array}$ & $\begin{array}{c}\text { Mean } \\
\text { Difference } \\
\text { (I-J) }\end{array}$ & $\begin{array}{c}\text { Significance } \\
\text { (P) }\end{array}$ \\
\hline \multirow{2}{*}{$\mathrm{A}$} & $\mathrm{B}$ & 0.8000 & 0.158 \\
\cline { 2 - 4 } & $\mathrm{C}$ & -0.5667 & 0.345 \\
\hline \multirow{2}{*}{$\mathrm{B}$} & $\mathrm{A}$ & -0.8000 & 0.158 \\
\cline { 2 - 4 } & $\mathrm{C}$ & -1.3667 & 0.024 \\
\hline \multirow{2}{*}{$\mathrm{C}$} & $\mathrm{A}$ & 0.5667 & 0.345 \\
\cline { 2 - 4 } & $\mathrm{B}$ & 1.3667 & 0.024 \\
\hline
\end{tabular}

Water vapor resistance was also evaluated for different raw materials. According to ANOVA test results, the raw material has a significant influence on the water vapor resistance values $(p=0.006)$. As seen in Figure 4, the water vapor resistance of 70/30 \% bamboo/cotton fabrics (C) is generally lower than that of other fabric types. According to the Tukey test results, the water vapor resistance value of 70/30\% bamboo/cotton (C) is statistically lower than that of $50 / 50 \%$ modal/cotton (F) fabrics. On the other hand, the differences between water vapor 


\section{H. G. TÜRKSOY, S. ÜSTÜNTAĞ, G. ÇARKIT / Thermal Comfort Properties of Fabrics Knitted from}

Bamboo/Cotton Blended Yarns

resistance of "C" with " $D$ " and "E" fabrics were found to be insignificant (Table 6).

Table 6. Multiple comparisons of raw materials for water vapor resistance.

\begin{tabular}{|c|c|c|c|}
\hline $\begin{array}{c}\text { Fabric } \\
\text { Type } \\
\text { (I) }\end{array}$ & $\begin{array}{c}\text { Fabric } \\
\text { Type } \\
\text { (J) }\end{array}$ & $\begin{array}{c}\text { Mean } \\
\text { Difference } \\
\text { (I-J) }\end{array}$ & $\begin{array}{c}\text { Significance } \\
\text { (P) }\end{array}$ \\
\hline \multirow{3}{*}{$\mathrm{C}$} & $\mathrm{D}$ & -0.8667 & 0.388 \\
\cline { 2 - 4 } & $\mathrm{E}$ & -0.4333 & 0.832 \\
\cline { 2 - 4 } & $\mathrm{F}$ & -2.5000 & 0.005 \\
\hline \multirow{3}{*}{$\mathrm{D}$} & $\mathrm{C}$ & 0.8667 & 0.388 \\
\cline { 2 - 4 } & $\mathrm{E}$ & 0.4333 & 0.832 \\
\cline { 2 - 4 } & $\mathrm{F}$ & -1.6333 & 0.051 \\
\hline \multirow{3}{*}{$\mathrm{E}$} & $\mathrm{C}$ & 0.4333 & 0.832 \\
\cline { 2 - 4 } & $\mathrm{D}$ & -0.4333 & 0.832 \\
\cline { 2 - 4 } & $\mathrm{F}$ & -2.0667 & 0.016 \\
\hline \multirow{3}{*}{$\mathrm{F}$} & $\mathrm{C}$ & 2.5000 & 0.005 \\
\cline { 2 - 4 } & $\mathrm{D}$ & 1.6333 & 0.051 \\
\cline { 2 - 4 } & $\mathrm{E}$ & 2.0667 & 0.016 \\
\hline \multirow{4}{*}{} & & & \\
\hline
\end{tabular}

The average thermal resistance values of the fabric samples are shown Figure 5. Thermal resistance was firstly evaluated for different fabric structures. As seen in Figure 5, the thermal resistance value of double knit (C) fabric is lower than that of plain knit (A) and pique knit (B) fabrics.

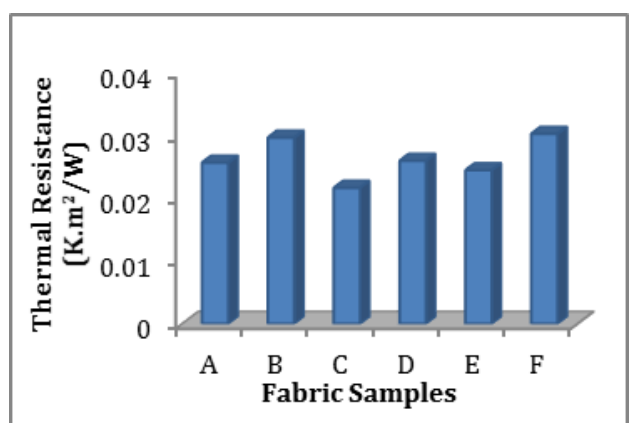

Figure 5. Thermal resistance values of fabric samples.

Table 7. Multiple comparisons of knitted structures for thermal resistance.

\begin{tabular}{|c|c|c|c|}
\hline $\begin{array}{c}\text { Fabric } \\
\text { Type } \\
\text { (I) }\end{array}$ & $\begin{array}{c}\text { Fabric } \\
\text { Type } \\
\text { (J) }\end{array}$ & $\begin{array}{c}\text { Mean } \\
\text { Difference } \\
\text { (I-J) }\end{array}$ & $\begin{array}{c}\text { Significance } \\
\text { (P) }\end{array}$ \\
\hline \multirow{2}{*}{$\mathrm{A}$} & $\mathrm{B}$ & -0.004 & 0.232 \\
\cline { 2 - 4 } & $\mathrm{C}$ & 0.004 & 0.232 \\
\hline \multirow{2}{*}{$\mathrm{B}$} & $\mathrm{A}$ & 0.004 & 0.232 \\
\cline { 2 - 4 } & $\mathrm{C}$ & 0.008 & 0.023 \\
\hline \multirow{2}{*}{$\mathrm{C}$} & $\mathrm{A}$ & -0.004 & 0.232 \\
\cline { 2 - 4 } & $\mathrm{B}$ & -0.008 & 0.023 \\
\hline
\end{tabular}

Based on the ANOVA results, the fabric structure has a significant effect on the thermal resistance values of bamboo/cotton fabrics with $p$-value 0.028. Tukey results show that the difference between thermal resistance values of double knit (C) and pique knit (B) fabrics is statistically significant whereas the difference between thermal resistance values of double knit (C) and plain knit (A) fabrics is insignificant. As can be seen from the Tukey results, the highest thermal resistance value was obtained from the 70/30 \% bamboo/cotton fabrics produced with pique knit structure and so this one ensures the best thermal isolation for the body (Table 7).

Table 8. Multiple comparisons of raw materials for thermal resistance.

\begin{tabular}{|c|c|c|c|}
\hline $\begin{array}{c}\text { Fabric } \\
\text { Type } \\
\text { (I) }\end{array}$ & $\begin{array}{c}\text { Fabric } \\
\text { Type } \\
\text { (J) }\end{array}$ & $\begin{array}{c}\text { Mean } \\
\text { Difference } \\
\text { (I-J) }\end{array}$ & $\begin{array}{c}\text { Significance } \\
\text { (P) }\end{array}$ \\
\hline \multirow{3}{*}{$\mathrm{C}$} & $\mathrm{D}$ & -0.004333 & 0.069 \\
\cline { 2 - 4 } & $\mathrm{E}$ & -0.002867 & 0.276 \\
\cline { 2 - 4 } & $\mathrm{F}$ & -0.008633 & 0.002 \\
\hline \multirow{3}{*}{$\mathrm{D}$} & $\mathrm{C}$ & 0.004333 & 0.069 \\
\cline { 2 - 4 } & $\mathrm{E}$ & 0.001467 & 0.751 \\
\cline { 2 - 4 } & $\mathrm{F}$ & -0.004300 & 0.072 \\
\hline \multirow{3}{*}{$\mathrm{E}$} & $\mathrm{C}$ & 0.002867 & 0.276 \\
\cline { 2 - 4 } & $\mathrm{D}$ & -0.001467 & 0.751 \\
\cline { 2 - 4 } & $\mathrm{F}$ & -0.005767 & 0.018 \\
\hline \multirow{3}{*}{$\mathrm{F}$} & $\mathrm{C}$ & 0.008633 & 0.002 \\
\cline { 2 - 4 } & $\mathrm{D}$ & 0.004300 & 0.072 \\
\cline { 2 - 4 } & $\mathrm{E}$ & 0.005767 & 0.018 \\
\hline
\end{tabular}

Thermal resistance was also evaluated for different raw materials. As seen in Figure 5, the thermal resistance value of $70 / 30 \%$ bamboo/cotton (C) fabric is the lower than that of other fabric types. According to the ANOVA, the raw material has a significant influence on the thermal resistance values $(\mathrm{p}=0.002)$. Tukey results show that the thermal resistance values of 70/30 \% bamboo/cotton (C) is statistically lower than that of $50 / 50 \%$ modal/cotton (F) fabrics. On the other hand, the differences between the mean thermal resistance values of 70/30 \% bamboo/cotton (C) and \%100 cotton (D), 
H. G. TÜRKSOY, S. ÜSTÜNTAĞ, G. ÇARKIT / Thermal Comfort Properties of Fabrics Knitted from Bamboo/Cotton Blended Yarns

\%100 modal (E) fabrics were found to be insignificant (Table 8).

\section{Discussion and Conclusion}

In this study, thermal comfort properties of the double knitted fabrics made from $70 / 30 \%$ bamboo/cotton blended yarns are investigated in comparison with the fabrics which have different fabric structures and raw materials. The effects of the fabric structure and fiber type on the thermal comfort properties were evaluated using the ANOVA and Tukey statistical analysis methods.

From the results, it has been proven that different fabric structures show different thermal comfort properties. According to the results, the highest water vapor resistance value was obtained from the double knit structure in 70/30 \% bamboo/cotton fabrics. This situation can be explained by the thickness of double knit fabric. Also, the highest air permeability values were obtained from the pique knit fabric as a result of the comparatively lower stitch density of pique knit fabrics (B) in comparison to the other fabric structures.

This study also revealed that fiber type is a significant factor for thermal comfort properties. Considering fiber type, the lowest water vapor resistance and thermal resistance values were obtained from 70/30 \% bamboo/cotton fabrics. This situation can be explained by the bamboo fiber properties such as high moisture absorption capacity and breathability.

\section{Acknowledgement}

We would like to express our sincere thanks to the research center of the Erciyes University for their financial assistance this research under contract FBY-12-3888.

\section{References}

[1] Fayala, F., Alibi, H., Benltoufa, S., Jemni, A., 2008. Neural Network for Predicting Thermal Conductivity of Knit Materials, Journal of Engineered Fibers and Fabrics, vol. 3, issue 4, p. 53-60.

[2] Avcl, H., 2005. Comfort Properties of Socks Produced with New Fabrics, Master's Thesis, Istanbul Technical University, İstanbul, Turkey.

[3] Karalomlu, E., 2010. Investigation of Comfort Properties of Functional Fabric which Used with Military Aim, Master's Thesis, Uludag University, Bursa, Turkey.

[4] Guignard, M. I., Farima, D., Ciobanu, L., Ciobanu, M., Gıraud, S., Campagne, C., Asavei, G. B., 2013. Comfort properties of knitted fabrics with massaging effects, Industria Textila, vol. 64, issue 1, p. 34-38.

[5] Kanat, Z., E., 2007. Comparison of Comfort Properties of Woven Fabrics Produced with Different Yarns, Master's Thesis, Ege University, Izmir, Turkey.

[6] Demiroz Gun A., Unal C., and Unal B. T., 2008. Dimensional and Physical Properties of Plain Knitted Fabrics Made from 50/50 Bamboo/Cotton Blended Yarns, Fibers and Polymers, vol. 9, issue 5, p. 588-592.

[7] Das, B., Das, A., Kothari, V., Fanguiero, R. ve Araújo, M. 2007. Moisture transmission through textiles Part I: Processes involved in moisture transmission and the factors at play, AUTEX Research Journal, vol. 7 (2), p. 100-110.

[8] Oğlakçıŏlu, N. ve Marmaralı, A. 2007. Thermal comfort properties of some knitted structures, Fibres \& Textiles in Eastern Europe, vol. 15 (5-6), p. 64-65.

[9] Nayak, R., Punj, S., Chatterjee, K. ve Behera, B., 2009. Comfort properties of suiting fabrics, Indian Journal of Fibre ve Textile Research, vol. 34, p. 122-128.

[10] Onofrei, E., Rocha, A. ve Catarino, A. 2011. The influence of knitted fabrics' structure on the thermal and moisture management properties, Journal of Engineered Fibers and Fabrics, vol. 6 (4), p. 10-22.

[11] Troynikov, O. ve Wardiningsih, W. 2011. Moisture management properties of wool/polyester and wool/bamboo knitted fabrics for the sportswear base 


\section{H. G. TÜRKSOY, S. ÜSTÜNTAĞ, G. ÇARKIT / Thermal Comfort Properties of Fabrics Knitted from}

Bamboo/Cotton Blended Yarns

layer, Textile Research Journal, vol. 81 (6), p. 621-631.

[12] Namligoz, E. S., Coban, S. ve Bahtiyari, M. I., 2010. Comparison of moisture transport properties of the various woven fabrics, Tekstil ve Konfeksiyon, vol. 20, p. 93-100.

[13] Prakash, C., Ramakrishnan, G., \& Koushik, C. V., 2012. A study of the thermal properties of single jersey fabrics of cotton, bamboo and cotton/bamboo blended yarn vis-a-vis bamboo fibre presence and yarn count, Journal of Thermal Analysis and Calorimetry, vol. 110, p. 1173-1177.

[14] Prakash, C., Ramakrishnan, G., \& Koushik, C. V., 2013. A study of the thermal properties of bamboo knitted fabrics, Journal of Thermal Analysis and Calorimetry, vol. 111, p. 101-105.

[15] Atasağun, H., Öner, E., Okur, A. ve Beden, A., 2015. A comprehensive study on the general performance properties of Viloft-blended knitted fabrics, The Journal of The Textile Institute, vol. 106 (5), p. 523-535.

[16] Büyükakıncı, B. Y., Sökmen, N., Öner, E., 2011. Investigating Dyeing Properties of Regenerated Bamboo Material Dyed with Reactive and Direct Dyes, Industria Textila, vol. 62, issue 2, p. 72-76.

[17] Wang, Y., Gao, X., 2004. Study on Structure of The Nature Bamboo Fiber, Proceedings of the Textile Institute 83rd World Conference, May 23-27, p. 135137.

[18] Erdumlu, N., Ozipek, B., 2008 Investigation of Regenerated Bamboo Fibre and Yarn Characteristics, Fibres and Textiles in Eastern Europe, vol. 16, issue 4 (69), p. 43-47.

[19] Ozgen, B., 2012. New Biodegradable Fibres, Yarn Properties and Their Applications in Textiles: A Review, Industria Textila, vol. 63, issue 1, p. 3-7.

[20] Mikucioniene, D., 2013. Arbataitis, E. Comparative Analysis of the Influence of Bamboo and Other Cellulose Fibres on Selected Structurel Prameters and Physical Properties of Knitted Fabrics, Fibres\&Textiles in Eastern Europe 2013, 21, 3(99):76-80.

[21] Majumdar, A., Mukhopadhyay, S., Yadav, R., 2010. Thermal Properties of Knitted Fabrics Made From Cotton and Regenerated Bamboo Cellulosic Fibres,
International Journal of Thermal Sciences, vol. 49, p. 2042-2048.

[22] Prakash, C., Ramakrishnan, G., 2013. Effect of Blend Ratio, Loop Length, and Yarn Linear Density on Thermal Comfort Properties of Single Jersey Knitted Fabrics, Int J Thermophys, vol 34, p. 113-121.

[23] ASTM D 1777-96, Standard Test Method for Thickness of Textile Materials

[24] ISO 9237-1999, Textiles-Determination of Permeability of Fabrics to Air.

[25] Demiroz Gun, A., 2011. Dimensional, Physical and Thermal Comfort Properties of Plain Knitted Fabrics Made from Modal Viscose Yarns Having Microfibers and Conventional Fibers, Fibers and Polymers, vol.12, issue 2, p 258-267.

[26] ISO 11092, $1993 . \quad$ TextilesDetermination of Physiological Properties-Measurement of Thermal and Water Vapor Resistance Under Steady-State Conditions (Sweating Guarded-Hotplate Test).

[27] Surdu, L., Ghituleasa, C., Mihai, C., Ene A., Radulescu, I., Subticica, A., Cioara, I., 2013. Comfort Properties of Multiayer Textile Materials for Clothing, Industria Textila, vol. 64, issue 2, p. 75-79. 